\title{
Changes of Metabolites and Macro- and Micro-elements in Hungarian Potatoes under Organic and Conventional Farming
}

\author{
Rita Tömösközi-Farkas ${ }^{1}$, Nóra Adányi ${ }^{1}$, Magdolna Gasztonyi-Nagy ${ }^{1}$, Mária Berki ${ }^{1}$, Viola Horváth ${ }^{2}$, Tibor \\ Renkecz ${ }^{3}$, Kinga Simon ${ }^{3}$, Zoltán Fabulya ${ }^{4}$ and Zsolt Polgár ${ }^{5}$ \\ 1. National Agricultural Research and Innovation Centre, Food Science Research Institute, Budapest H-1022, Hungary \\ 2. Research Group for Technical Analytical Chemistry, Hungarian Academy of Sciences, Budapest University of Technology and \\ Economics, Budapest H-1111, Hungary \\ 3. Department of Inorganic and Analytical Chemistry, Budapest University of Technology and Economics, Budapest H-1111, \\ Hungary \\ 4. Department of Engineering, University of Szeged, Szeged H-6720, Hungary \\ 5. Potato Research Centre, University of Pannonia, Keszthely H-8360, Hungary
}

\begin{abstract}
To study the effect of cultivation system (conventional and organic) on potato tuber components, 42 parameters (anti-nutritives, micro- and macro-elements and 23 metabolites) were studied in three multi-resistant Hungarian potato varieties for three years in 2007-2009. Discriminant analysis of data proved that all investigated factors (farming technology, genotype and season/year) had significant effect on metabolites. Reversed phase high performance liquid chromatographic (HPLC-DAD, HPLC-MS) and elemental analysis methods have been adapted to quantify the major components, i.e., steroidal alkaloids, nitrite, nitrate, sugars, amino acids and micro-elements, in potato tubers. The absolute amount and changes of tuber components were influenced differentially by the technology, genotype and season in a complex manner. Any examined component, except nitrate content, was found to be significantly higher or lower consistently in relation to the production practice (organic or conventional) during the three years trials. Under the examined circumstances, no consequent positive effect of organic farming on the total amount of anti-nutritive components, vitamins or micro- and macro-elements of potato tubers could be proven.
\end{abstract}

Key words: Potato, organic farming, conventional farming, metabolomics, macro- and micro-elements.

\section{Introduction}

Potato (Solanum tuberosum) is the third most important staple food crop after wheat and rice worldwide, and plays a significant role in human diet [1]. Conventional potato production is largely depended on the intensive use of fertilizers and pesticides, leading to serious environmental and food safety concerns. Production under organic conditions may have positive effect to overcome such problems. Moreover, some studies concluded that vegetables

Corresponding author: Zsolt Polgár, professor, research fields: potato breeding and genetics. originating from organic production are richer in nutrients, particularly organic acids, vitamins and polyphenols than the conventionally produced ones [2]. Other studies however could not confirm such significant differences in products produced by either way [3].

Organic growers must face to difficulties in terms of dealing with adequate plant nutrients, especially nitrogen application, weed, insect and disease control issues. A review on the problem of pest management in organic potato production has been published by Pesticide Action Network (PAN), Europe [4]. The use of varieties having wide range of adaptability to 
diverse environmental factors [5], better nitrogen use efficiency [6] and resistance against major pathogens and pests $[7,8]$ are prerequisites for the successful organic potato production. Potato varieties may differ dramatically in all the above listed traits [9-11]. However, the knowledge about the performance of different varieties under conventional and organic farming and the effect of applied farming practices on the tuber components is rather limited [12-15].

New potatoes cultivars with stable yield both in volume and quality due to their elevated and complex environmental adaptability (to pets, pathogens, climate and nutrition) suit more to the requirements of organic production. In general, breeders utilize wild relatives of cultivated potato as source of resistance genes in breeding programmes. The complex genetic background of new cultivars released from such programmes may result in the altered metabolome of the tubers, compared to traditional ones. The goal of this study was to compare the metabolites, micro- and macro-elements of three Hungarian potato varieties (Hópehely, White Lady, Rioja) having complex resistance traits to biotic and abiotic stresses in relation to conventional and organic farming technology. Further, the aim was to identify potentially typical (marker) components connected to the farming technology.

\section{Materials and Methods}

\subsection{Chemicals}

The standard materials of metabolites, sodium 1-heptane-sulfonate, ammonium phosphate, ammonium acetate, acetic acid and ammonia were purchased from Sigma-Aldrich Ltd. (St Louis, USA). Acetonitrile, acetic acid, potassium hexacyanoferrate (II), zinc acetate, sulphanilamide chloride and n-(1-naphtyl) ethylene diamine were purchased from Merck (Darmstadt, Germany). Acids used for sample digestion were of Hiperpur grade from Pancreac (Darmstadt, Germany). Standard solutions for element analysis were purchased from Carlo Erba (Paris,
France), Merck and Pancreac. All reagents were of analytical reagent grade. Ultrapure water generated by the Milli-Q System (Millipore, Darmstadt, Germany) was used. All reagents were used without additional cleaning. SPE cartridge (ENVI-18 $6 \mathrm{~mL}$ ) and PTFE sample filter $(25 \mathrm{~mm} \times 0.45 \mu \mathrm{m})$ were purchased from SUPELCO Co. (St Louis, USA).

\subsection{Plant Materials and Growth Condition}

Potato varieties, Rioja, Hópehely and White Lady, originate from the commercial breeding programme of University of Pannonia, Potato Research Centre, Keszthely, Hungary. The varieties show complex resistance to abiotic stresses (heat, drought and uneven water supply), as well as to potato viruses: potato virus $\mathrm{Y}$ (PVY), potato virus $\mathrm{X}$ (PVX), potato virus $\mathrm{A}$ (PVA), potato leaf roll virus (PLRV) and to common scab (Streptomyces scabies). Hópehely and White Lady are resistant to potato golden cyst nematode (Globodera rostochiensis, pathotype Ro1 and Ro4) and potato wart (Synchytrium endobioticum), while White Lady has high field resistance to potato late blight (Phytophthora infestans) as well. During their breeding, exotic potato species, like S. acaule, S. demissum, S. stoloniferum, S. vernei, and S. tuberosum ssp. andigena were used as source of resistance genes.

Varieties were cultivated under conventional (at Keszthely on brown light clay soil) and organic (at Rábcakapi on peaty chernozem soil) farming conditions, in Hungary in a four plot randomized replicated trial (56 plants/plot in two rows) in three seasons of 2007-2009. Planting was in April, and harvest was in August, summer seasons. Organic farming conditions, applied plant nutrition and plant protection, were certified by Biocontroll Hungária Nonprofit Ltd.. Soil parameters were determined by official soil sampling and measurements. Nutrient supply capacity of the two soil type for N, P and K did not differ significantly at moderate supply capacity level, except humus content which was $1.64 \%$ at Keszthely and $2.4 \%$ at Rábcakapi. No irrigation was 
applied at any of the locations. Natural precipitation in vegetation period (May-August) was 320, 295 and 265 $\mathrm{mm}$ at Keszthely, and 360, 324 and $288 \mathrm{~mm}$ at Rábcakapi in the years of 2007, 2008 and 2009, respectively, close to 100 year average for Keszthely, $294 \mathrm{~mm}$. The applied plant protection technologies allowed healthy plant development till natural maturing.

\subsection{Tuber Sampling}

After harvest, $20 \mathrm{~kg}$ of tubers from each experimental plot representing the farming technologies were collected. For the three parallel measurements, three tubers originated from three different plants were selected and prepared to get homogenous samples.

\subsection{Potato Processing}

Potatoes were washed, peeled ( $2 \mathrm{~mm}$ thickness) according to the food processing technology, and crushed by chopper (Philips HR 1392). All samples were then freeze dried and subjected to further analysis. The lyophilised samples were ground to powder (Bosch MKM6003) and stored at room temperature. The investigated components are stable at room temperature, and the preliminary experiments proved that under the applied circumstances, the freeze drying method did not damage any of these compounds.

\subsection{Chemical Determination}

\subsubsection{Glycoalkaloid Analysis}

Alkaloid content of tuber samples was determined according to the protocol published by
Tömösközi-Farkas et al. [16].

\subsubsection{Analysis of Metabolites by HPLC-MS}

$50 \mathrm{mg}$ of the lyophilized potato tuber sample was extracted with $1 \mathrm{~mL}$ water for $30 \mathrm{~min}$ in an ultrasonic bath, then centrifuged for $10 \mathrm{~min}$ at $2,000 \times \mathrm{g}$. The supernatant was complemented to eluent composition with ammonium acetate and acetonitrile, and centrifuged for $10 \mathrm{~min}$ at $30,000 \times \mathrm{g}$. After, $5 \mu \mathrm{L}$ of the sample was injected into a Perkin Elmer Series 200 chromatograph. The components were separated on a $150 \mathrm{~mm} \times 2.1 \mathrm{~mm}, 5 \mu \mathrm{m}$, ZIC-HILIC (Merck) column by gradient elution at a flow rate of $150 \mathrm{~L} / \mathrm{min}$. Mobile phase component A was $20 \mathrm{mM}$ ammonium acetate ( $\mathrm{pH} 4.0$ ), and component B was acetonitrile. From 0 min to 8 min, mobile phase B was kept at $80 \%$, from $8 \mathrm{~min}$ to $20 \mathrm{~min}$, it was decreased to $40 \%$, and then kept at this value for $3 \mathrm{~min}$. The analysis was performed with a Perkin Elmer Sciex API 365 triple quadrupole mass spectrometer with an ESI ion source (Sciex, Toronto, Canada) in positive multiple reaction monitoring mode. Asparagine and glutamine were measured at the $\mathrm{m} / \mathrm{z}$ (mass-to-charge ratio) 133.1 to 73.9 and $\mathrm{m} / \mathrm{z} 147.1$ to 84.1 transitions, respectively, and quantitated using calibration standards prepared from an amino acid standard mix (Sigma-Aldrich).

2.5.3 Macro- and Micro-elements Analysis by Atomic Absorption Spectroscopy (AAS)

The measurements of macro- and micro-elements were carried out using Solaar M5 (Thermo Elemental, Waltham, MA, USA) double-beam atomic absorption spectrometer in line with the official AOAC Method [17]. The instrument settings are detailed in Table 1.

Table 1 Instrument settings of element analysis by AAS.

\begin{tabular}{|c|c|c|c|c|c|}
\hline Element & Technique & Wavelength (nm) & Bandpass (nm) & Background correction & Ionisation buffer \\
\hline $\mathrm{K}$ & Flame, emission & 766.5 & 0.5 & - & $0.2 \%(\mathrm{~m} / \mathrm{V}) \mathrm{CsCl}$ \\
\hline $\mathrm{Na}$ & Flame, emission & 589.0 & 0.5 & - & $0.2 \%(\mathrm{~m} / \mathrm{V}) \mathrm{CsCl}$ \\
\hline $\mathrm{Ca}$ & Flame, absorption & 422.7 & 0.5 & - & $0.2 \%(\mathrm{~m} / \mathrm{V}) \mathrm{LaCl}_{3}$ \\
\hline $\mathrm{Mg}$ & Flame, absorption & 285.2 & 0.5 & D2 lamp & $0.2 \%(\mathrm{~m} / \mathrm{V}) \mathrm{LaCl}_{3}$ \\
\hline $\mathrm{Fe}$ & Flame, absorption & 248.3 & 0.2 & D2 lamp & - \\
\hline $\mathrm{Cu}$ & Flame, absorption & 324.8 & 0.5 & D2 lamp & - \\
\hline $\mathrm{Zn}$ & Flame, absorption & 213.9 & 0.5 & D2 lamp & - \\
\hline $\mathrm{Mn}$ & Flame, absorption & 279.5 & 0.2 & D2 lamp & - \\
\hline
\end{tabular}


First, $0.5 \mathrm{~g}$ of lyophilized potato samples were digested in closed system with $10 \mathrm{~mL}$ of concentrated nitric acid. After cooling, the samples were diluted to $20 \mathrm{~mL}$ with bidistilled water and stored in refrigerator until measurement. Before measuring macro-element composition, samples were diluted with ionisation buffer up to the appropriate rate.

\subsubsection{Analysis of Nitrite and Nitrate Content}

Determination of nitrite and nitrate content were carried out by molecular absorption spectrometric method according to the standard method of AOAC Official Method 993.03 [17].

\subsection{Statistical Analysis}

Statistical analyses, discriminant analysis and Mann-Whitney test of experimental data were performed by IBM SPSS Statistics 20 software.

\section{Results and Discussion}

Collected data were evaluated in terms of the effect of farming technology, genotype and year on the main characteristic compounds, anti-nutritive components and overall metabolite composition of potato tubers. On the basis of three year results, no clear tendencies among measured parameters were found, since the amount of some components, such as glycine, cysteine,

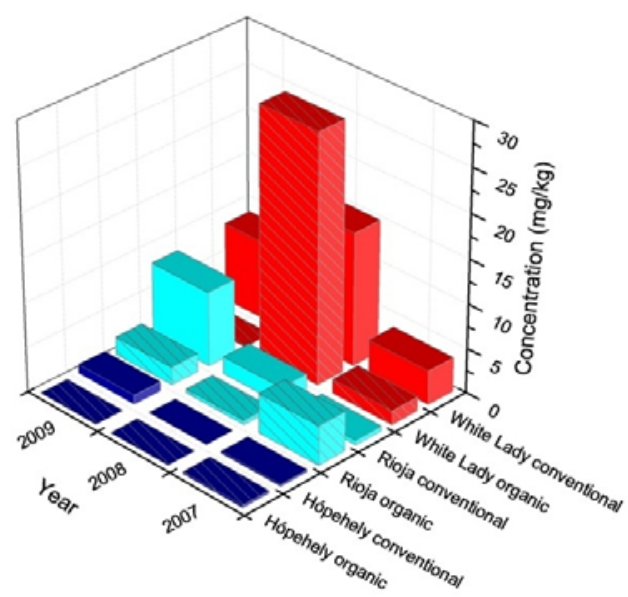

(a) Total glycoalkaloid vitamin $\mathrm{C}$ and methionine, did not change, while others increased (sucrose) or decreased (nitrate). Based on previous supposition, organically grown potato tubers should have altered metabolite profile compared to conventionally grown ones. Some of these alterations could have positive or negative effect on consumers. In some former studies, Asami et al. [18] reported the elevated accumulation of certain elements, phenolic compounds, glycoalkaloids and other metabolites in organic potatoes compared to conventionally grown ones. This phenomenon was believed to be caused by the higher nitrogen availability of soil and the influence of biotic and abiotic stresses.

\subsection{Seasonal Effect}

During the three years period, the direction of changes was different. For example, in the case of variety Rioja, the significantly higher amount of total glycoalkaloid content was found in 2007 from organic production, there were no differences in 2008 , while the conventional circumstances resulted in a significantly higher total glycoalkaloid content concentration in the third year 2009 (Fig. 1). In case of nitrate, significant differences were found between the years, and the conventional samples had higher concentration of this component in almost all the cases.

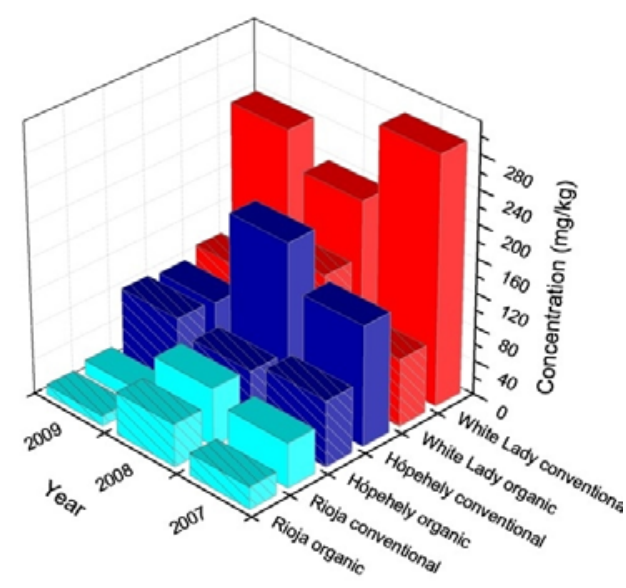

(b) Total nitrate

Fig. 1 Effect of conventional and organic farming technology on total glycoalkaloid (a) and nitrate (b) content of potato tubers of White Lady, Rioja and Hópehely in 2007-2009. 
Considering the organic farming technology during the three years, amino acid concentration increased in 2007, did not change in 2008 and decreased in 2009 in White Lady variety. In Rioja, the conventional technology resulted in higher amino acid content mostly, and in Hópehely variety all the data were not markedly different during the three years (Table 2). In summary, the season affected significantly both the direction of the changing and the absolute volume of all the investigated metabolites.

\subsection{Effect of Cultivar}

The genetic background was also proved to be a determinative factor for the metabolite composition of tubers, although the season had great influence on the changes as well. For example, the least changes were detected in Hópehely cultivar. From 21 measured amino acids, the amount of 16,15 and 9 did not change irrespective of farming system in 2007, 2008 and 2009, respectively. While in case of White Lady, the amount of amino acids did not change in 6, 21, 7 and for Rioja 4, 13, 15 cases (Table 2). Free amino acids have been shown to critically affect several parameters during potato processing, including the flavour of cooked potato. Maggio et al. [12] investigated the yield and metabolite profile of potato under conventional and organic farming. Their results proved that cultivation system and cultivar are both important in determining the levels of free amino acids. Of all the amino acids quantified, glutamine and glutamate showed the largest change in response to different treatments.

The amount of the monosaccharides and disaccharides were significantly different for each of the varieties during the whole study, resembling to the strong genotype effect on these parameters. Shepherd et al. [19] showed that variation in acrylamide producing potential in potato depends on both asparagine and reducing sugars levels. They emphasized that conventional breeding programmes need to select for both low reducing sugar and asparagine level simultaneously to have reduced acrylamide content in the processed products.

The results in this study proved the higher importance of genetic background on nitrogen accumulation of tubers in respect of farming technology. Conventional farming resulted in higher nitrate content in White Lady, Hópehely and Rioja, but at different level (Fig. 1). On the other hand, comparing all the nitrate and nitrite values in White Lady, Hópehely, Rioja cultivars during the three years period, it can be stated that Rioja under conventional system accumulated significantly lower amount of nitrate than the other two cultivars grown under organic circumstances.

Herencia et al. [14] have conducted a comparative long-term study of organic versus mineral fertilisation (with bean, carrot, cauliflower, fallow, lettuce, marrow, melon, pepper, potatoes, strawberry, tomatoes and watermelon crops) for nine years in Spain. They found a tendency for lower $\mathrm{N}$ and higher $\mathrm{P}$ content in organic crops cultivated in the same crop cycle, while $\mathrm{K}$ concentration did not show a clear trend.

\subsection{Effect of Farming Technology}

$\mathrm{N}$ content in potato tubers can be present either in the form of proteins, amino acids or nitrates and glycoalkaloids. According to the results in this study, the total amount of amino acids were significantly higher in conventionally grown potatoes than in organic ones, but these differences were not traceable in case of every amino acids (Table 1). These forms are very important with respect to possible impacts on human health. In general, under conventional farming, potatoes are fertilized by a lot of easily available $\mathrm{N}$ and minerals. This is most probably the main reason of higher nitrate content in conventionally grown potatoes in all the three years (Fig. 1) as compared to organic samples. The measured differences were significant in all the cases. The data observed in this study confirmed the results of several former publications [13, 20-23]. 
Table 2 Differences in the amount of metabolites, micro- and macro-elements between conventionally and organically cultivated potatoes.

\begin{tabular}{|c|c|c|c|c|c|c|c|c|c|c|}
\hline \multicolumn{2}{|c|}{ Components } & \multicolumn{3}{|c|}{2007} & \multicolumn{3}{|c|}{2008} & \multicolumn{3}{|c|}{2009} \\
\hline & & White lady & Rioja & Hópehely & White lady & Rioja & Hópehely & White lady & Rioja & Hópehely \\
\hline 1 & Alanine & $\mathrm{C}<\mathrm{O}$ & $\mathrm{C}>\mathrm{O}$ & $\mathrm{C}>\mathrm{O}$ & $\mathrm{C}=\mathrm{O}$ & $\mathrm{C}=\mathrm{O}$ & $\mathrm{C}=\mathrm{O}$ & $\mathrm{C}>\mathrm{O}$ & $\mathrm{C}=\mathrm{O}$ & $\mathrm{C}>\mathrm{O}$ \\
\hline 2 & Cysteine & $\mathrm{C}=\mathrm{O}$ & $\mathrm{C}=\mathrm{O}$ & $\mathrm{C}=\mathrm{O}$ & $\mathrm{C}=\mathrm{O}$ & $\mathrm{C}=\mathrm{O}$ & $\mathrm{C}=\mathrm{O}$ & $\mathrm{C}=\mathrm{O}$ & $\mathrm{C}=\mathrm{O}$ & $\mathrm{C}=\mathrm{O}$ \\
\hline 3 & Asparagic acid & $\mathrm{C}<\mathrm{O}$ & $\mathrm{C}<\mathrm{O}$ & $\mathrm{C}=\mathrm{O}$ & $\mathrm{C}=\mathrm{O}$ & $\mathrm{C}=\mathrm{O}$ & $\mathrm{C}=\mathrm{O}$ & $\mathrm{C}=\mathrm{O}$ & $\mathrm{C}=\mathrm{O}$ & $\mathrm{C}=\mathrm{O}$ \\
\hline 4 & Glutamic acid & $\mathrm{C}=\mathrm{O}$ & $\mathrm{C}<\mathrm{O}$ & $\mathrm{C}<\mathrm{O}$ & $\mathrm{C}=\mathrm{O}$ & $\mathrm{C}=\mathrm{O}$ & $\mathrm{C}=\mathrm{O}$ & $\mathrm{C}>\mathrm{O}$ & $\mathrm{C}=\mathrm{O}$ & $\mathrm{C}>\mathrm{O}$ \\
\hline 5 & Phenylalanine & $\mathrm{C}<\mathrm{O}$ & $\mathrm{C}>\mathrm{O}$ & $\mathrm{C}=\mathrm{O}$ & $\mathrm{C}=\mathrm{O}$ & $\mathrm{C}=\mathrm{O}$ & $\mathrm{C}=\mathrm{O}$ & $\mathrm{C}>\mathrm{O}$ & $\mathrm{C}=\mathrm{O}$ & $\mathrm{C}>\mathrm{O}$ \\
\hline 6 & Glycine & $\mathrm{C}=\mathrm{O}$ & $\mathrm{C}=\mathrm{O}$ & $\mathrm{C}=\mathrm{O}$ & $\mathrm{C}=\mathrm{O}$ & $\mathrm{C}=\mathrm{O}$ & $\mathrm{C}=\mathrm{O}$ & $\mathrm{C}=\mathrm{O}$ & $\mathrm{C}=\mathrm{O}$ & $\mathrm{C}=\mathrm{O}$ \\
\hline 7 & Histidine & $\mathrm{C}<\mathrm{O}$ & $\mathrm{C}>\mathrm{O}$ & $\mathrm{C}=\mathrm{O}$ & $\mathrm{C}=\mathrm{O}$ & $\mathrm{C}=\mathrm{O}$ & $\mathrm{C}=\mathrm{O}$ & $\mathrm{C}=\mathrm{O}$ & $\mathrm{C}=\mathrm{O}$ & $\mathrm{C}=\mathrm{O}$ \\
\hline 8 & Iso-leucine & $\mathrm{C}<\mathrm{O}$ & $\mathrm{C}>\mathrm{O}$ & $\mathrm{C}=\mathrm{O}$ & $\mathrm{C}=\mathrm{O}$ & $\mathrm{C}=\mathrm{O}$ & $\mathrm{C}=\mathrm{O}$ & $\mathrm{C}>\mathrm{O}$ & $\mathrm{C}=\mathrm{O}$ & $\mathrm{C}>\mathrm{O}$ \\
\hline 9 & Leucine & $\mathrm{C}<\mathrm{O}$ & $\mathrm{C}>\mathrm{O}$ & $\mathrm{C}=\mathrm{O}$ & $\mathrm{C}=\mathrm{O}$ & $\mathrm{C}>\mathrm{O}$ & $\mathrm{C}=\mathrm{O}$ & $\mathrm{C}>\mathrm{O}$ & $\mathrm{C}=\mathrm{O}$ & $\mathrm{C}>\mathrm{O}$ \\
\hline 10 & Methionine & $\mathrm{C}=\mathrm{O}$ & $\mathrm{C}=\mathrm{O}$ & $\mathrm{C}=\mathrm{O}$ & $\mathrm{C}=\mathrm{O}$ & $\mathrm{C}=\mathrm{O}$ & $\mathrm{C}>\mathrm{O}$ & $\mathrm{C}=\mathrm{O}$ & $\mathrm{C}<\mathrm{O}$ & $\mathrm{C}=\mathrm{O}$ \\
\hline 11 & Asparagine & $\mathrm{C}<\mathrm{O}$ & $\mathrm{C}>\mathrm{O}$ & $\mathrm{C}=\mathrm{O}$ & $\mathrm{C}=\mathrm{O}$ & $\mathrm{C}>\mathrm{O}$ & $\mathrm{C}>\mathrm{O}$ & $\mathrm{C}>\mathrm{O}$ & $\mathrm{C}>\mathrm{O}$ & $\mathrm{C}=\mathrm{O}$ \\
\hline 12 & Proline & $\mathrm{C}=\mathrm{O}$ & $\mathrm{C}>\mathrm{O}$ & $\mathrm{C}>\mathrm{O}$ & $\mathrm{C}=\mathrm{O}$ & $\mathrm{C}>\mathrm{O}$ & $\mathrm{C}>\mathrm{O}$ & $\mathrm{C}>\mathrm{O}$ & $\mathrm{C}<\mathrm{O}$ & $\mathrm{C}=\mathrm{O}$ \\
\hline 13 & Lysine & $\mathrm{C}<\mathrm{O}$ & $\mathrm{C}>\mathrm{O}$ & $\mathrm{C}=\mathrm{O}$ & $\mathrm{C}=\mathrm{O}$ & $\mathrm{C}>\mathrm{O}$ & $\mathrm{C}=\mathrm{O}$ & $\mathrm{C}>\mathrm{O}$ & $\mathrm{C}>\mathrm{O}$ & $\mathrm{C}>\mathrm{O}$ \\
\hline 14 & Glutamine & $\mathrm{C}<\mathrm{O}$ & $\mathrm{C}>\mathrm{O}$ & $\mathrm{C}=\mathrm{O}$ & $\mathrm{C}=\mathrm{O}$ & $\mathrm{C}=\mathrm{O}$ & $\mathrm{C}>\mathrm{O}$ & $\mathrm{C}>\mathrm{O}$ & $\mathrm{C}=\mathrm{O}$ & $\mathrm{C}=\mathrm{O}$ \\
\hline 15 & Arginine & $\mathrm{C}<\mathrm{O}$ & $\mathrm{C}>\mathrm{O}$ & $\mathrm{C}=\mathrm{O}$ & $\mathrm{C}=\mathrm{O}$ & $\mathrm{C}=\mathrm{O}$ & $\mathrm{C}=\mathrm{O}$ & $\mathrm{C}=\mathrm{O}$ & $\mathrm{C}=\mathrm{O}$ & $\mathrm{C}>\mathrm{O}$ \\
\hline 16 & Serine & $\mathrm{C}>\mathrm{O}$ & $\mathrm{C}>\mathrm{O}$ & $\mathrm{C}<\mathrm{O}$ & $\mathrm{C}=\mathrm{O}$ & $\mathrm{C}>\mathrm{O}$ & $\mathrm{C}>\mathrm{O}$ & $\mathrm{C}>\mathrm{O}$ & $\mathrm{C}>\mathrm{O}$ & $\mathrm{C}>\mathrm{O}$ \\
\hline 17 & Threonine & $\mathrm{C}<\mathrm{O}$ & $\mathrm{C}>\mathrm{O}$ & $\mathrm{C}=\mathrm{O}$ & $\mathrm{C}=\mathrm{O}$ & $\mathrm{C}=\mathrm{O}$ & $\mathrm{C}=\mathrm{O}$ & $\mathrm{C}>\mathrm{O}$ & $\mathrm{C}=\mathrm{O}$ & $\mathrm{C}>\mathrm{O}$ \\
\hline 18 & Valine & $\mathrm{C}<\mathrm{O}$ & $\mathrm{C}>\mathrm{O}$ & $\mathrm{C}=\mathrm{O}$ & $\mathrm{C}=\mathrm{O}$ & $\mathrm{C}>\mathrm{O}$ & $\mathrm{C}=\mathrm{O}$ & $\mathrm{C}>\mathrm{O}$ & $\mathrm{C}=\mathrm{O}$ & $\mathrm{C}>\mathrm{O}$ \\
\hline 19 & Tryptophan & $\mathrm{C}<\mathrm{O}$ & $\mathrm{C}>\mathrm{O}$ & $\mathrm{C}=\mathrm{O}$ & $\mathrm{C}=\mathrm{O}$ & $\mathrm{C}>\mathrm{O}$ & $\mathrm{C}>\mathrm{O}$ & $\mathrm{C}>\mathrm{O}$ & $\mathrm{C}=\mathrm{O}$ & $\mathrm{C}>\mathrm{O}$ \\
\hline 20 & Tyrosine & $\mathrm{C}<\mathrm{O}$ & $\mathrm{C}>\mathrm{O}$ & $\mathrm{C}>\mathrm{O}$ & $\mathrm{C}=\mathrm{O}$ & $\mathrm{C}>\mathrm{O}$ & $\mathrm{C}=\mathrm{O}$ & $\mathrm{C}>\mathrm{O}$ & $\mathrm{C}>\mathrm{O}$ & $\mathrm{C}>\mathrm{O}$ \\
\hline 21 & Cysteine & $\mathrm{C}=\mathrm{O}$ & $\mathrm{C}=\mathrm{O}$ & $\mathrm{C}=\mathrm{O}$ & $\mathrm{C}=\mathrm{O}$ & $\mathrm{C}=\mathrm{O}$ & $\mathrm{C}=\mathrm{O}$ & $\mathrm{C}=\mathrm{O}$ & $\mathrm{C}=\mathrm{O}$ & $\mathrm{C}=\mathrm{O}$ \\
\hline 22 & Quinic acid & $\mathrm{C}<\mathrm{O}$ & $\mathrm{C}>\mathrm{O}$ & $\mathrm{C}>\mathrm{O}$ & $\mathrm{C}=\mathrm{O}$ & $\mathrm{C}>\mathrm{O}$ & $\mathrm{C}>\mathrm{O}$ & $\mathrm{C}>\mathrm{O}$ & $\mathrm{C}=\mathrm{O}$ & $\mathrm{C}=\mathrm{O}$ \\
\hline 23 & Malic acid & $\mathrm{C}=\mathrm{O}$ & $\mathrm{C}>\mathrm{O}$ & $\mathrm{C}>\mathrm{O}$ & $\mathrm{C}=\mathrm{O}$ & $\mathrm{C}>\mathrm{O}$ & $\mathrm{C}>\mathrm{O}$ & $\mathrm{C}>\mathrm{O}$ & $\mathrm{C}<\mathrm{O}$ & $\mathrm{C}>\mathrm{O}$ \\
\hline 24 & Mannitol & $\mathrm{C}>\mathrm{O}$ & $\mathrm{C}=\mathrm{O}$ & $\mathrm{C}=\mathrm{O}$ & $\mathrm{C}=\mathrm{O}$ & $\mathrm{C}>\mathrm{O}$ & $\mathrm{C}>\mathrm{O}$ & $\mathrm{C}=\mathrm{O}$ & $\mathrm{C}<\mathrm{O}$ & $\mathrm{C}=\mathrm{O}$ \\
\hline 25 & Succinic acid & $\mathrm{C}=\mathrm{O}$ & $\mathrm{C}>\mathrm{O}$ & $\mathrm{C}=\mathrm{O}$ & $\mathrm{C}=\mathrm{O}$ & $\mathrm{C}=\mathrm{O}$ & $\mathrm{C}=\mathrm{O}$ & $\mathrm{C}<\mathrm{O}$ & $\mathrm{C}=\mathrm{O}$ & $\mathrm{C}=\mathrm{O}$ \\
\hline 26 & Sucrose & $\mathrm{C}<\mathrm{O}$ & $\mathrm{C}<\mathrm{O}$ & $\mathrm{C}<\mathrm{O}$ & $\mathrm{C}<\mathrm{O}$ & $\mathrm{C}<\mathrm{O}$ & $\mathrm{C}<\mathrm{O}$ & $\mathrm{C}=\mathrm{O}$ & $\mathrm{C}>\mathrm{O}$ & $\mathrm{C}=\mathrm{O}$ \\
\hline 27 & Fructose & $\mathrm{C}=\mathrm{O}$ & $\mathrm{C}>\mathrm{O}$ & $\mathrm{C}>\mathrm{O}$ & $\mathrm{C}<\mathrm{O}$ & $\mathrm{C}=\mathrm{O}$ & $\mathrm{C}=\mathrm{O}$ & $\mathrm{C}=\mathrm{O}$ & $\mathrm{C}=\mathrm{O}$ & $\mathrm{C}=\mathrm{O}$ \\
\hline 28 & Glucose & $\mathrm{C}=\mathrm{O}$ & $\mathrm{C}>\mathrm{O}$ & $\mathrm{C}>\mathrm{O}$ & $\mathrm{C}=\mathrm{O}$ & $\mathrm{C}=\mathrm{O}$ & $\mathrm{C}=\mathrm{O}$ & $\mathrm{C}=\mathrm{O}$ & $\mathrm{C}=\mathrm{O}$ & $\mathrm{C}<\mathrm{O}$ \\
\hline 29 & Citric acid & $\mathrm{C}<\mathrm{O}$ & $\mathrm{C}<\mathrm{O}$ & $\mathrm{C}<\mathrm{O}$ & $\mathrm{C}=\mathrm{O}$ & $\mathrm{C}=\mathrm{O}$ & $\mathrm{C}=\mathrm{O}$ & $\mathrm{C}<\mathrm{O}$ & $\mathrm{C}<\mathrm{O}$ & $\mathrm{C}=\mathrm{O}$ \\
\hline 30 & Vitamin C & $\mathrm{C}<\mathrm{O}$ & $\mathrm{C}=\mathrm{O}$ & $\mathrm{C}<\mathrm{O}$ & $\mathrm{C}=\mathrm{O}$ & $\mathrm{C}<\mathrm{O}$ & $\mathrm{C}=\mathrm{O}$ & nd & nd & nd \\
\hline 31 & Nitrite & $\mathrm{C}=\mathrm{O}$ & $\mathrm{C}=\mathrm{O}$ & $\mathrm{C}=\mathrm{O}$ & $\mathrm{C}=\mathrm{O}$ & $\mathrm{C}=\mathrm{O}$ & $\mathrm{C}=\mathrm{O}$ & $\mathrm{C}=\mathrm{O}$ & $\mathrm{C}=\mathrm{O}$ & $\mathrm{C}>\mathrm{O}$ \\
\hline 32 & Nitrate & $\mathrm{C}>\mathrm{O}$ & $\mathrm{C}>\mathrm{O}$ & $\mathrm{C}>\mathrm{O}$ & $\mathrm{C}>\mathrm{O}$ & $\mathrm{C}>\mathrm{O}$ & $\mathrm{C}>\mathrm{O}$ & $\mathrm{C}>\mathrm{O}$ & $\mathrm{C}>\mathrm{O}$ & $\mathrm{C}=\mathrm{O}$ \\
\hline 33 & $\begin{array}{l}\text { Total } \\
\text { glycoalkaloids }\end{array}$ & $\mathrm{C}>\mathrm{O}$ & $\mathrm{C}<\mathrm{O}$ & $\mathrm{C}=\mathrm{O}$ & $\mathrm{C}=\mathrm{O}$ & $\mathrm{C}=\mathrm{O}$ & $\mathrm{C}=\mathrm{O}$ & $\mathrm{C}>\mathrm{O}$ & $\mathrm{C}>\mathrm{O}$ & $\mathrm{C}=\mathrm{O}$ \\
\hline 34 & Dry matter & $\mathrm{C}=\mathrm{O}$ & $\mathrm{C}<\mathrm{O}$ & $\mathrm{C}=\mathrm{O}$ & $\mathrm{C}<\mathrm{O}$ & $\mathrm{C}<\mathrm{O}$ & $\mathrm{C}<\mathrm{O}$ & $\mathrm{C}>\mathrm{O}$ & $\mathrm{C}>\mathrm{O}$ & $\mathrm{C}>\mathrm{O}$ \\
\hline 35 & $\mathrm{Mg}$ & $\mathrm{C}<\mathrm{O}$ & $\mathrm{C}<\mathrm{O}$ & $\mathrm{C}<\mathrm{O}$ & $\mathrm{C}=\mathrm{O}$ & $\mathrm{C}=\mathrm{O}$ & $\mathrm{C}=\mathrm{O}$ & $\mathrm{C}<\mathrm{O}$ & $\mathrm{C}=\mathrm{O}$ & $\mathrm{C}<\mathrm{O}$ \\
\hline 36 & $\mathrm{Ca}$ & $\mathrm{C}>\mathrm{O}$ & $\mathrm{C}=\mathrm{O}$ & $\mathrm{C}>\mathrm{O}$ & $\mathrm{C}=\mathrm{O}$ & $\mathrm{C}=\mathrm{O}$ & $\mathrm{C}>\mathrm{O}$ & $\mathrm{C}<\mathrm{O}$ & $\mathrm{C}=\mathrm{O}$ & $\mathrm{C}<\mathrm{O}$ \\
\hline 37 & $\mathrm{Na}$ & $\mathrm{C}<\mathrm{O}$ & $\mathrm{C}<\mathrm{O}$ & $\mathrm{C}<\mathrm{O}$ & $\mathrm{C}=\mathrm{O}$ & $\mathrm{C}=\mathrm{O}$ & $\mathrm{C}=\mathrm{O}$ & $\mathrm{C}=\mathrm{O}$ & $\mathrm{C}<\mathrm{O}$ & $\mathrm{C}=\mathrm{O}$ \\
\hline 38 & $\mathrm{~K}$ & $\mathrm{C}=\mathrm{O}$ & $\mathrm{C}=\mathrm{O}$ & $\mathrm{C}=\mathrm{O}$ & $\mathrm{C}=\mathrm{O}$ & $\mathrm{C}=\mathrm{O}$ & $\mathrm{C}=\mathrm{O}$ & $\mathrm{C}=\mathrm{O}$ & $\mathrm{C}=\mathrm{O}$ & $\mathrm{C}<\mathrm{O}$ \\
\hline 39 & $\mathrm{Cu}$ & $\mathrm{C}>\mathrm{O}$ & $\mathrm{C}<\mathrm{O}$ & $\mathrm{C}>\mathrm{O}$ & $\mathrm{C}=\mathrm{O}$ & $\mathrm{C}=\mathrm{O}$ & $\mathrm{C}=\mathrm{O}$ & $\mathrm{C}=\mathrm{O}$ & $\mathrm{C}<\mathrm{O}$ & $\mathrm{C}=\mathrm{O}$ \\
\hline 40 & $\mathrm{Fe}$ & $\mathrm{C}=\mathrm{O}$ & $\mathrm{C}=\mathrm{O}$ & $\mathrm{C}=\mathrm{O}$ & $\mathrm{C}=\mathrm{O}$ & $\mathrm{C}=\mathrm{O}$ & $\mathrm{C}=\mathrm{O}$ & $\mathrm{C}>\mathrm{O}$ & $\mathrm{C}=\mathrm{O}$ & $\mathrm{C}>\mathrm{O}$ \\
\hline 41 & $\mathrm{Zn}$ & $\mathrm{C}=\mathrm{O}$ & $\mathrm{C}=\mathrm{O}$ & $\mathrm{C}=\mathrm{O}$ & $\mathrm{C}=\mathrm{O}$ & $\mathrm{C}=\mathrm{O}$ & $\mathrm{C}=\mathrm{O}$ & $\mathrm{C}=\mathrm{O}$ & $\mathrm{C}=\mathrm{O}$ & $\mathrm{C}<\mathrm{O}$ \\
\hline 42 & $\mathrm{Mn}$ & $\mathrm{C}<\mathrm{O}$ & $\mathrm{C}<\mathrm{O}$ & $\mathrm{C}<\mathrm{O}$ & $\mathrm{C}=\mathrm{O}$ & $\mathrm{C}=\mathrm{O}$ & $\mathrm{C}=\mathrm{O}$ & $\mathrm{C}>\mathrm{O}$ & $\mathrm{C}=\mathrm{O}$ & $\mathrm{C}=\mathrm{O}$ \\
\hline
\end{tabular}

$\mathrm{C}<\mathrm{O}$ : organic results significantly higher; $\mathrm{C}>\mathrm{O}$ : conventionally significantly higher; $\mathrm{C}=\mathrm{O}$ : no significant difference; nd: no data. 
Changes of Metabolites and Macro- and Micro-elements in Hungarian

Potatoes under Organic and Conventional Farming

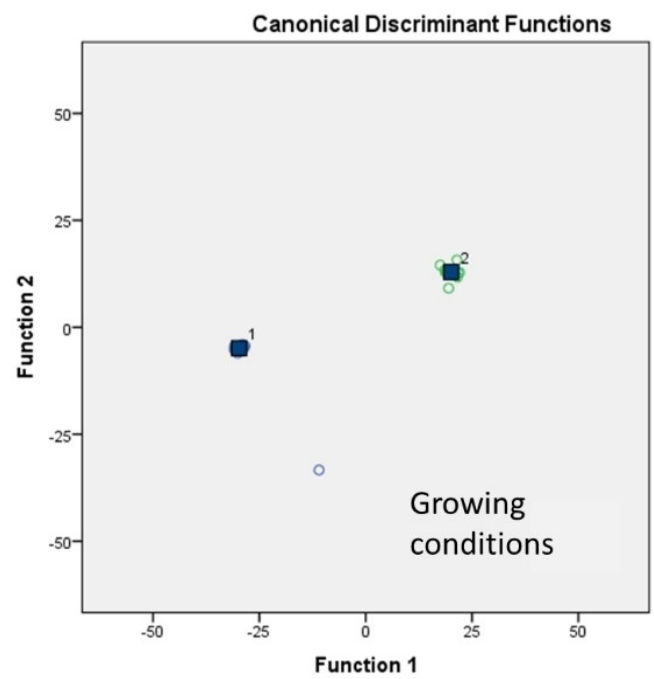

VAR00001

1. Conventional

2. Organic

(a) Different farming technologies Canonical Discriminant Functions

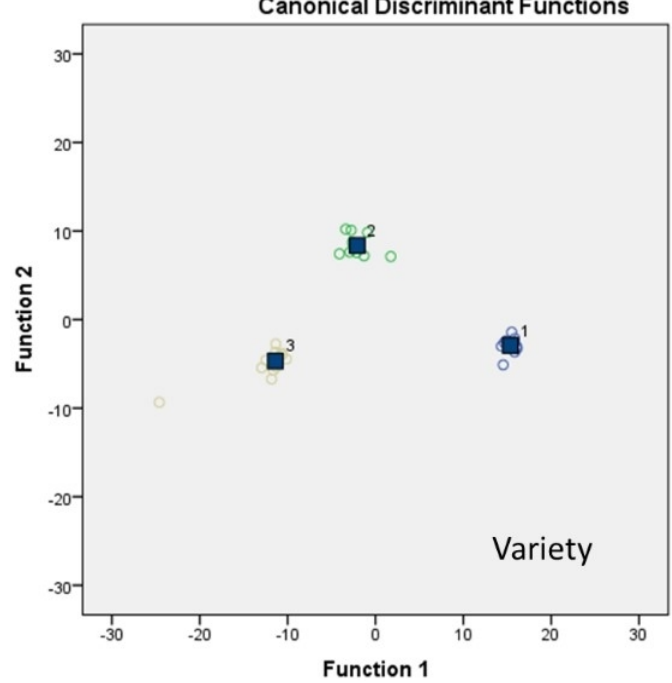

\section{VAR00002}

1 White Lady

2 Rioja

3 Hópehely

(b) Different varieties

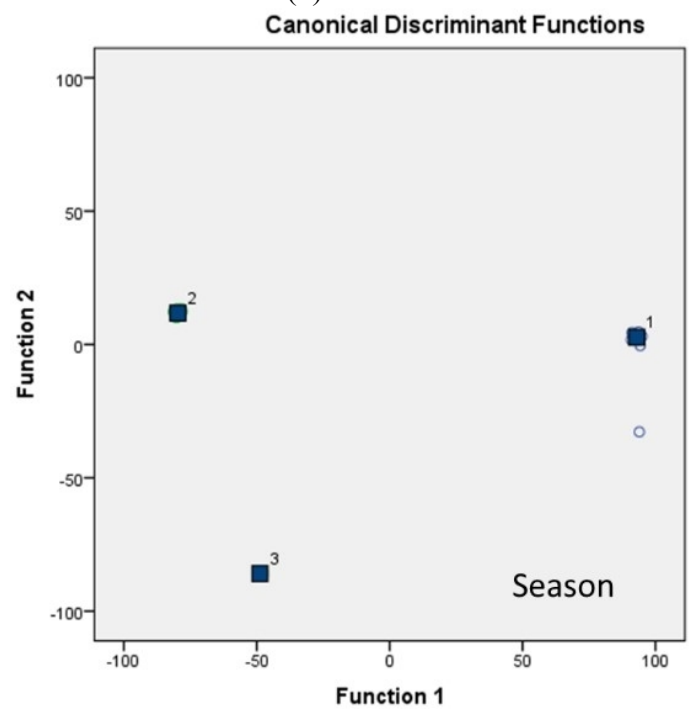

VAR00003

1. 2007

2. 2008

3. 2009

(c) Different seasons

Fig. 2 Canonical discriminant analysis of metabolites in potato grown organically and conventionally (a) in different varieties (b) and season 2007-2009 (c). 
The amount of micro- and macro-elements of the examined samples originating from different locations and farming technologies did not show clear significant differences. It could not prove any clear effect of farming technology on the mineral content of potato tubers (Table 2).

Wszelaki et al. [24] found differences among field treatments in mineral content of potato. $\mathrm{P}$ and $\mathrm{Mg}$ levels were higher in organic than in conventionally grown tubers. $\mathrm{K}, \mathrm{S}$ and $\mathrm{Cu}$ concentrations were also found to be higher in organic tubers in the same study. Several other authors found higher $\mathrm{Mg}$ content in organically grown tubers $[15,25-27]$. The results in the present study showed a similar tendency. Mg level was usually higher in organic samples than in conventional potatoes, but there were no significant differences found in $\mathrm{K}$ concentration and the results of $\mathrm{Cu}$ level were not consequent (Table 2).

There is no consensus in the literature on the impact of farming technology on $\mathrm{Ca}$ content in potato tubers. In organically grown potatoes, Smith [25] and Worthington [28] found more $\mathrm{Ca}$ than in conventional tubers, Lombardo et al. [27] found more accumulated $\mathrm{Ca}$ in conventional potatoes, while Hoefkens et al. [29] found no difference between the two groups. The results in this study proved that the season had more effect on $\mathrm{Ca}$ accumulation than the cultivation. Conventional potatoes contained higher $\mathrm{Ca}$ concentration in the years of 2007 and 2008, but organic samples had higher in 2009.

The amount of steroidal alkaloids in potato tubers is determined genetically, but the growing and storage conditions have great impact on it. Hajslova et al. [13] and Hoefkens et al. [29] found that organically grown potatoes accumulated more alkaloids than conventionally grown ones. Skrabule et al. [30] under a two-year trial found that farming technology parameters had significant effect on alkaloids in one of the years. The results observed from this study did not prove these results. The conventional potatoes accumulated greater amount of alkaloids in 2009, there were no significant differences in none of varieties in 2008, while the conventional White Lady and organically grown Rioja contained higher amount of alkaloids in 2007.

Musilova et al. [31] proved that the soil $\mathrm{N}$ content and the influence of biotic and abiotic stresses have a great effect on the development of higher glycoalkaloid and phenolic content in organically grown potatoes. The results in this paper are ambiguous, no any component, except nitrate content, were found significantly higher or lower consistently in organically or conventionally grown potatoes. However, by the discriminant analysis of investigated parameters, the organically and conventionally grown samples could be clearly grouped into two distinct groups. The same situation was got in the case of analysing seasonal and variety effects, too (Fig. 2).

The special requirements needed to follow by an organic fruit or vegetables grower in general do not allow to practice conventional agriculture on the same farm or close neighbourhood. In practice, there are really a few farmers, who could manage both farming technologies and supply experimental samples of the same cultivars. In this study, the potato samples are not only different in terms of the farming technology, but somewhat in the ecological situation of the production site, too. Although soil analysis did not show significant differences between the two site, one can suppose other factors, like slight difference in amount of precipitation, average temperatures or duration and intensity of light (last three, not recorded parameters in this case), may also take part in the fine forming of metabolite development.

\section{Conclusions}

The market supposes higher nutritional value of organically grown raw materials and processed products as compared to conventional ones. The results from this paper are ambiguous, no any examined component, except nitrate content, were found to be significantly higher or lower consistently 
in relation to the production practice (organic or conventional) during the three-year trials. The clear influence of farming technology on the metabolite profile of potato tubers, which affects their food value positively or negatively, could not be proved, since basically the genotype and furthermore the ecological conditions, such as soil, season, pressure of pathogens, pests, etc., play also an important role in the metabolite accumulation. These modifying parameters are able to mask the light effect of production technologies by either positive or negative way. In spite of all, in food industry especially for baby food, the processing varieties accumulating genetically low amount of nitrate should be preferred for organic farming.

\section{Acknowledgments}

The financial support of the National Scientific Research Fund (OTKA 68706) is greatly appreciated.

\section{References}

[1] FAO. 2008. "International Year of the Potato, 2008." Accessed June 12, 2016. http://www.potato2008.org/en/world/index.html.

[2] Winter, C. K., and Davis, S. F. 2006. "Organic Foods." Journal of Food Science 71 (9): 117-24.

[3] Warman, P. R. 2008. "Soil Fertility, Yield and Nutrient Contents of Vegetable Crop after 12 Years of Compost or Fertilizer Amendments." Biological Agriculture and Horticulture 23 (1): 85-96.

[4] Tresnik, S. 2007. "State of the Art of Integrated Crop Management and Organic Systems in Europe, with Particular Reference to Pest Management: Potato Production." Pesticide Action Network (PAN), Europe Accessed January, 2007. http://www.pan-europe.info/old/Resources/Reports/Potat o_production_review.pdf.

[5] Hassanpanah, D. 2010. "Analysis of $G \times E$ Interaction by Using the Additive Main Effects and Multiplicative Interaction in Potato Cultivars." International Journal of Plant Breeding and Gene 4 (1): 23-9.

[6] Gholipouri, A. M., and Kandi, A. S. 2012. "Evaluating of Nitrogen Use Efficiency's as Affected by Different Nitrogen Fertilizers Levels on Potato Varieties." Advances in Environmental Biology 6 (2): 774-8.

[7] Salazar, L. F. 1996. Potato Viruses and Their Control. Lima, Peru: International Potato Center (CIP).
[8] Forbs, G. A. 1999. "Genotype by Environmental Reaction of Potato to the Late Blight Pathogen." In Impact on a Changing World: Program Report 1997-98. Lima, Peru: International Potato Center (CIP), 57-66.

[9] Polgar, Z., Cernak, I., and Vaszily, Z. 2016. "Potato Breeding, Meeting the Challenges of Climate Change." In Proceedings of International Conference on "Climate Changes, a Permanent Challenge for Agricultural Research on Potato, Sugar Beet, Cereals and Medicinal Plants", 25-7.

[10] Polgar, Z., Wolf, I., Vaszily, Z., Tömösközi-Farkas, R., and Gergely, L. 2010. "The Newest Results of a Complex Resistance Breeding Programme to Biotic and Abiotic Stresses of Potato." In Proceedings of International Symposium on Agronomy and Physiology of Potato, 69-75.

[11] Hoffmann, B., Hoffmann, S., and Polgár, Z. 2010. "Screening for Nitrogen Use Efficiency (NUE) in Hungarian Potato Cultivars." In Proceedings of the XVII Congress of the Federation of European Societies of Plant Biology (FESPB 2010), 135-6.

[12] Maggio, A., Carillo, P., Bulmetti, G. S., Fuggi, A., Barbieri, G., and De Pascale, S. 2008. "Potato Yield and Metabolic Profiling under Conventional and Organic Farming." European Journal of Agronomy 28: 343-50.

[13] Hajslova, J., Schulzova, V., Slanina, P., Janne, K., Hellenas, K. E., and Andersson, C. 2005. "Quality of Organically and Conventionally Grown Potatoes: Four-Year Study of Micronutrients, Metals, Secondary Metabolites, Enzymic Browning and Organoleptic Properties." Food Additives and Contaminants 22 (6): 514-34.

[14] Herencia, J. F., Garcia-Galavis, P., Dorado, J. A., and Maqueda, C. 2011. "Comparison of Nutritional Quality of the Crops Grown in an Organic and Conventional Fertilized Soil." Scientia Horticulturae 129 (4): 882-8.

[15] Warman, P. R., and Havard, K. A. 1998. "Yield, Vitamin and Mineral Contents of Organically and Conventionally Grown Potatoes and Sweet Corn." Agriculture, Ecosystems \& Environment 68 (3): 207-16.

[16] Tömösközi-Farkas, R., Daood, H. G., Polgár, Z., and Hajós, G. 2006. "Determination of Glycoalkaloids in Hungarian Potatoes by HPLC." Chromatographia 63: $115-8$.

[17] Association of Official Analytical Chemists (AOAC). 2003. AOAC Official Method 993.03.

[18] Asami, D. K., Hong, Y. J., Barrett, D. M., and Mitchell, A. E. 2003. "Comparison of the Total Phenolic and Ascorbic Acid Content of Freeze-Dried and Air-Dried Marionberry, Strawberry and Corn Grown Using Conventional, Organic and Sustainable Agricultural Practices." J. Agric. Food Chem. 51 (5): 1237-41.

[19] Shepherd, L. V. T., Bradshaw, J. E., Dale, M. F. B., 
McNicol, J. W., Pont, S. D. A., Mottram, D. S., and Davies, H. V. 2010. "Variation in Acrylamide Producing Potential in Potato: Segregation of the Trait in a Breeding Population." Food Chemistry 123 (3): 568-73.

[20] Lairon, D., Termine, E., Gauthier, S., and Lafont, H. 1985. "Nitrate Content of Vegetable Crops Produced by Organic Farming Methods." Science des Aliments 5: 337-43. (in French)

[21] Rembialkowska, E. 1999. "Comparison of the Contents of Nitrates, Nitrites, Lead, Cadmium and Vitamin C in Potatoes from Conventional and Ecological Farms." Polish Journal of Food and Nutrition Sciences 8 (4): 17-26.

[22] Guziur, J., Schulzová, V., and Hajslová, J. 2000. "Influence of Production Site and Way of Growing on the Chemical Composition of Potato Tubers." Bramborarství 8 (1): 6-7. (in Czech)

[23] Lombardo, S., Pandino, G., and Mauromicale, G. 2012. "Nutritional and Sensory Characteristics of 'Early' Potato Cultivars under Organic and Conventional Cultivation Systems." Food Chemistry 133 (4): 1249-54.

[24] Wszelaki, A. L., Delwiche, J. F., Walker, S. D., Liggett, R. E., Scheerens, J. C., and Kleinhenz, M. D. 2005. "Sensory Quality and Mineral and Glycoalkaloid Concentrations in Organically and Conventionally Grown Redskin Potatoes (Solanum tuberosum)." Journal of the Science of Food and Agriculture 85 (5): 720-6.

[25] Smiths, B. L. 1993. "Organic Foods vs. Supermarket
Foods: Element Levels." Journal of Applied Nutrition 45 (1): 35-9.

[26] Lairon, D. 2010. "Nutritional Quality and Safety of Organic Food: A Review." Agronomy for Sustainable Development 30 (1): 33-41.

[27] Lombardo, S., Pandino, G., and Mauromicale, G. 2014. "The Mineral Profile in Organically and Conventionally Grown 'Early' Crop Potato Tubers." Scientia Horticulturae 167: 169-73.

[28] Worthington, V. J. 2001. "Nutritional Quality of Organic Versus Conventional Fruits, Vegetables and Grains." J. Altern. Complement. Med. 7 (2): 161-73.

[29] Hoefkens, C., Vandekinderen, I., De Meulenaer, B., Devlieghere, F., Baert, K., Sioen, I., De Henauw, S., Verbeke, W., and Van Camp, J. 2009. "A Literature-Based Comparison of Nutrient and Contaminant Contents between Organic and Conventional Vegetables and Potatoes." British Food Journal 111 (10): 1078-97.

[30] Skrabule, I., Muceniece, R., and Kirhnere, I. 2013. "Evaluation of Vitamins and Glycoalkaloids in Potato Genotypes Grown under Organic and Conventional Farming Systems." Potato Research 56 (4): 259-76.

[31] Musilová, J., Lachma, J., Bystrick, J., Poláková, Z., Kováči, P., and Hrabovská, D. 2013. "The Changes of the Polyphenol Content and Antioxidant Activity in Potato Tubers (Solanum tuberosum L.) Due to Nitrogen Fertilization.” Potravinarsko 7 (1): 164-70. 